\title{
Meta-Analysis Study: Reading Behavior Of Food Products Label
}

\author{
Ujang Sumarwan \\ Department of Family and \\ Consumer Sciences, Faculty of \\ Human Ecology, \\ Bogor Agricultural University
}

\author{
Megawati Simanjuntak* \\ Department of Family and \\ Consumer Sciences, Faculty \\ of Human Ecology, \\ Bogor Agricultural University
}

\author{
Lilik Noor Yuliati \\ Department of Family and \\ Consumer Sciences, \\ Faculty of Human \\ Ecology, \\ Bogor Agricultural \\ University
}

\begin{abstract}
Labels are an integral part of a product. Observing the labels on the packaging, especially food products is considered very important to do. However, the label of food packaging products receives less attention from consumers. Therefore, the public is required to be more ingenious in observing the label of food packaging products to avoid food security problems which have adverse health effects. The purpose of this study was to map the results of research on label reading behavior. The design of this study was a literature study of research results that can be accessed via the internet. The results showed that the behavior of reading food product labels was done before buying the product (Aulawi 2005; Susanto 2008; Kumalasari and Sjafei 2012). From the frequency of reading nutrition labels, it could be found out that 42.5 percent of consumers sometimes read and 30.2 percent often read food packaging labels (Andrias 2016). Of the 52 studies, 17 studies have shown that women often read more and notice label attributes on food product packaging. The most commonly read consumer label (Figure 3 ) was the kosher $\log$ o and nutritional value. Food products that are usually labeled are packaged foods. Nutrition and health claims are considered as a means of education for consumers 14 percent to know new information and 86 percent of consumers decided to read the labels because of the outside factors, such as advertising, internet, or at school.
\end{abstract}

Keywords: food label, food label reading behavior

Abstrak. Label merupakan bagian tak terpisahkan dari sebuah produk. Mengamati label yang tertera pada kemasan khususnya produk pangan memang dirasa sangat penting dilakukan. Namun, label produk kemasan pangan kurang mendapat perhatian dari konsumen. Oleh karena itu masyarakat dituntut untuk lebih cerdik dalam mengamati label kemasan produk pangan, agar terhindar dari masalah keamanan pangan dan yang berdampak buruk bagi kesehatan. Tujuan penelitian ini adalah untuk memetakan hasilhasil penelitian tentang perilaku membaca label. Desain penelitian ini adalah studi literatur hasil-hasil penelitian yang dapat diakses melalui internet. Hasil penelitian menunjukkan, Perilaku membaca label produk pangan dilakukan sebelum membeli produk (Aulawi 2005; Susanto 2008; Kumalasari dan Sjafei 2012). Frekuensi membaca label gizi, 42,5 persen konsumen terkadang membaca dan sebesar 30,2 persen sering membaca label makanan kemasan (Andrias 2016). Dari 52 studi, 17 penelitian membuktikan bahwa perempuan lebih sering membaca dan memerhatikan atribut label pada kemasan produk pangan. Label yang paling sering dibaca konsumen (Gambar 3) adalah $\log$ o halal dan nilai gizi. Produk pangan yang biasa dibaca labelnya adalah makanan kemasan. klaim gizi dan kesehatan dianggap dapat menjadi sarana edukasi untuk mengetahui informasi baru oleh konsumen sebesar 14 persen dan 86 persennya dipengaruhi faktor luar antara lain iklan, internet, atau pada saat sekolah.

Kata kunci: label pangan, perilaku membaca label pangan 


\section{Introduction}

Labels are an integral part of a product. Consumer's concern over packaged food product information tends to focus on nutritional value, expired date and the ingredients used in the product. The effectiveness of label utilization as one source of product information and product quality will depend on the level of consumer awareness and understanding of the information submitted. The large number of processed food and beverage products on the market makes label and packaging important thing to note.

Observing the labels on the packaging, especially food products is considered very important to do. Unfortunately according to the results of research Rahayu et. Al. (2013) it shows that the habit of reading food labels on students is only 30.3 percent. Meanwhile, the results of the Consumer Protection Agency study shows that the label of food packaging products receives less attention from consumers, only about 6.7 percent of consumers who pay attention to the completeness of labels on packaging products (BPKN 2007). These data illustrated that the habits of consumers to read the label is still relatively low. Therefore, the public is required to be more ingenious in observing the label of food packaging products to avoid food security problems which have adverse health effects. It also causes the increasingly complex information received by consumers (Rahayu et al., 2013).

Research on label reading habit has done in many circles, such as academics, government institutions, and non-government institutions, etc. For that we need to study literature study related to the behavior of reading food labels to determine the factors that influence the behavior of reading the label, and its influence on purchasing decisions and its impact on the health degree.

Based on the above description, there are research questions such as: 1) Whether consumers read the labels on food products and when consumers read the labels; 2) How consumer demographics read the labels; 3) On what elements / sections are read and on the front or back label or both; 4) What food products the label reads; 5) Does the consumer know and understand the information intended on the label, such as claims, nutritional value information, halal logo and other logos, if there is a health message about non-communicable diseases on the packaging label, will it affect consumers to choose products; 6) Is there a relationship between reading the label with nutritional knowledge; 7) What information is on the label taken into consideration at the time of purchase; 8) Does label reading behavior affect the purchase of food packaging; And 9) How recommendations on research topics related to food labels.

The purpose of this study was to map out research results on label reading behavior, among others: (1) label reading behavior on food products and time / situation reading packaging labels; (2) Social, economic and demographic characteristics of consumers reading the label; (3) The portion of the label that the consumer reads, i.e. what parts are read and the front label and / or back labels; (4) Food products normally labeled; (5) to know and understand the information contained on the label, among others: Food packaging design; Claims, food additives; Halal logo; Health messages surrounding non-communicable diseases on packaging labels; (6) The relationship between reading labels with nutritional knowledge; (7) Information contained on the label taken into consideration at the time of purchase; (8) The influence of label reading behavior with the purchase of 
food packaging; And (9) Recommendations on research topics related to food labeling.

\section{Method}

The design of this study was a literature study of research results that can be accessed via the internet. This research was conducted from November 2016 to January 2017.

In the literature search process, there are several keywords used for each of the following aspects, such as labeling, front-of-pack labeling, halal labeling, nutrition information, composition, expiration, label knowledge, label reading behavior, label reading frequency, label reading time, products purchased, packaged foods, beverage packaging, nutritional claims, health claims, knowledge relationships and label reading behavior, and behavioral relationships with decision making (17 keywords).

The literature search is conducted online from various available sources (open access) that have been summarized in Table 1.

Table 1 Site address used in online literature search

\begin{tabular}{|c|c|}
\hline Journal/Institution & Adress \\
\hline \multicolumn{2}{|l|}{ Literature search engine } \\
\hline SciELO & www.scielosp.org \\
\hline Pubmed & http://www.ncbi.nlm.nih.gov/pubmed \\
\hline Science Direct & http://www.sciencedirect.com \\
\hline Research Gate & www.reasearchgate.net \\
\hline AgEcon Search & Ageconsearch.umn.edu \\
\hline \multicolumn{2}{|l|}{ Journal } \\
\hline Journal of Nutrition & jurnal.unimus.ac.id \\
\hline Journal of Family and Consumer Science & journal.ipb.ac.id \\
\hline Journal of Economics and Finance & jurnal.usu.ac.id \\
\hline Scientific Journal of Student Management & journal.wima.ac.id \\
\hline ASEAN/Asian & aasic.org \\
\hline \multicolumn{2}{|l|}{ International Conference } \\
\hline Asian Social Science & www.ccsenet.org \\
\hline Journal of Business Strategy and Execution & journal.binus.ac.id \\
\hline Journal of Medical Internet Research & www.jmir.org \\
\hline Health Promotion International & http://heapro.oxfordjournals.org \\
\hline \multicolumn{2}{|l|}{ Institution } \\
\hline Bogor Agricultural University & http://repository.ipb.ac.id/ \\
\hline University of Airlangga & http://repository.unair.ac.id/ \\
\hline University of Muhammadiyah Surakarta & https://publikasiilmiah.ums.ac.id \\
\hline The University of Adelaide & https://digital.library.adelaide.edu.au \\
\hline
\end{tabular}

\section{Result and Discussion}

\section{Food Label}

Food labels can be divided into two parts, namely the label on the front (front) that contains important information needed by the community and the information on the back. Front labels include trademark, product name, product type, halal logo, net weight, and registration number / PIRT. Rear label includes 
nutrition, expiry, composition, product description, manufacturer description, and other logo information. In addition, there is labeling of nutritional claims and health claims.

\section{Study Profile}

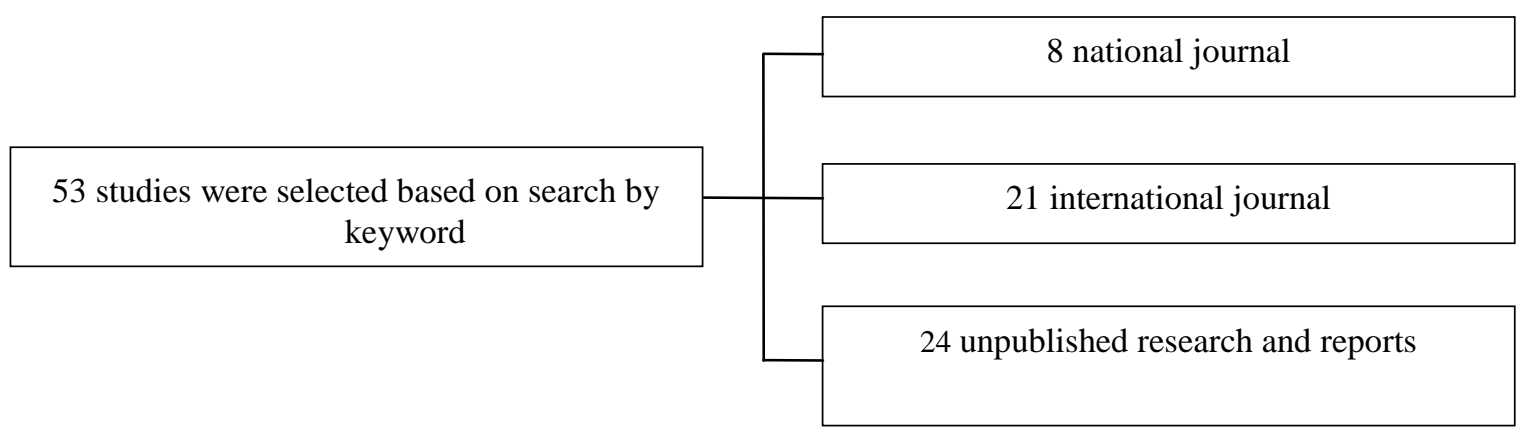

Figure 1 Selected chart of study type

The study process needs 63 references. This can be Identified by the type of literature that has been summarized (Figure 1). There are 51 studies that are adequate the keyword and literature criteria on food labels. The research were conducted in Indonesia amounting to 32 libraries and from outside Indonesia, there were as many as 21 libraries. Figure 2 categorizes study results by year of publication and research methods that used.

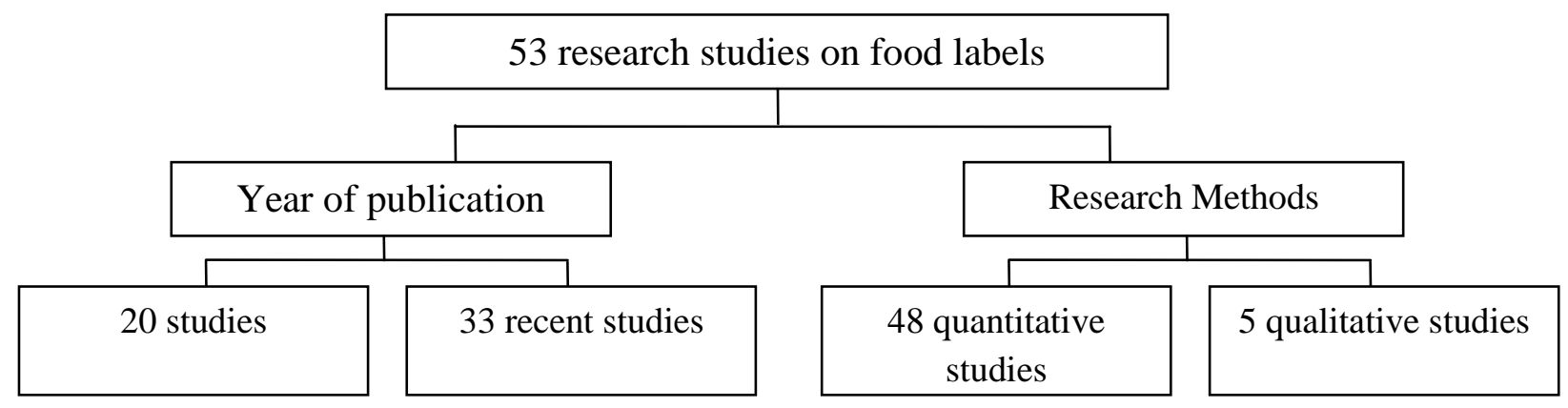

Figure 2 Chart of Study Type

\section{Label Reading Behavior on Food Products}

Consumer behavior is all activities, actions, and psychological processes that encourage such actions before buying, when buying, when using, when spending products and services after doing the above or evaluating activities (Sumarwan 2011).

The label reading behavior on food products is done before buying the product (Aulawi 2005; Susanto 2008; Kumalasari and Sjafei 2012; Azman and Sahak 2014; Ruwani et al. 2014). Respondents who paid attention to the food packaging label before buying food amounted to 61.2 percent (Susanto 2008) with a factor influencing the respondent's attention to the food packaging label is the 
source of information. The Kumalasari and Sjafei (2012) study focuses on consumer behavior in calculating calories before purchasing a particular product and proving that product purchase decisions are based on the calorie calculations listed (Azman and Sahak 2014).

The frequency of reading nutritional labels is categorized by 42.5 percent of consumers sometimes read and by 30.2 percent often read food packaging labels (Andrias 2016). The Toiba study (2015) proves that consumers never read the label (36.95\%) and sometimes read the label $(32.11 \%)$ and rarely read the nutritional label of food packaging products (Barreiro-Hurle et al 2010, Dewantara 2014; Mediani 2014).

\section{Characteristics of Social, Economic and Demographic Consumers who are Reading Labels}

\section{Label Reading Behavior by Sex}

Research based on sex group is divided into three, that is, mix of female and male respondents, female respondents only, and male respondents only. Research focusing on women and men as consumers is Kleef et research. Al. (2007) and Campos et. Al. (2011) which proves that women are more confident in labeling on food products and will use them than men. Furthermore, Syarifah (2009) proves that women prefer food products that affect health. Grunert et. Al. (2010) also proves that women prefer food products for health reasons and tend to pay attention to nutritional value information compared to men. De la Cruz-Gongora et. Al. (2012) proves that women are 6 percent more likely to read nutritional value information than men. Similar research results are also found in Hong et. Al. (2011), Lin et. Al. (2011), Andrias (2016), and Fadlillah (2016) which prove that women tend to read labels on products compared to men. Besler et. Al. (2012) and Kurnia et. Al. (2016) also proves that women often read the label of nutritional value information more than men.

\section{Label Based Reading Behavior Level of Living Standard Measure (NGO)}

The results of Puspitalena (2016) showed that 70 percent of respondents read the label of dairy products for children 1-3 years, 30 percent of respondents said sometimes reading the label and no respondent said that they did not read the label. The reason was that they did not understand the contents $(53 \%)$ and $20 \%$ of respondents said that it is just the same as previous product (20\%) they bought. In addition, higher expenditure relationships are found for products and the role of nutritional and health claims. The above description states that the higher the education or the higher monthly family expenditure or spending on growth milk for children aged 1-3 years, the greater the influence of the role of nutritional and health claims as a determinant of purchases and the tendency of consumers to read the label.

\section{Label Reading Behavior Based on Research Sites}

Ruwani's (2014) study found that consumers in urban and rural areas assume that food demand is obtained from both packaged and non-packaged foods. Ruwani (2014) found that about 97 percent of urban households buys dairy/processed products and about 90 percent buys snacks every month. This 
proves that the food packaging becomes one of the needs of consumers in urban as well as in rural areas. Based on the research conducted by Ruwani (2014) it can be concluded that consumers who live in urban areas have a tendency to read the label of food products compared to consumers who live in rural areas.

\section{Part Label Read Consumer}

Front labels include trademarks that are the trade names of companies, the product names describe the nature of the information or the actual state of the food (Ginting 2016). The type of product is the category of food sold and the halal logo is a certificate sign that the product can be consumed by Muslims. Net weight or net content is a statement that indicates the quantity or quantity of food products in the packaging (Ginting 2016). In addition, there is a registration number / PIRT on the front which is the license certificate number stating that the product has passed the clinical trial issued by the Provincial Health Office.

Syarifah (2009) examines attributes on yogurt packaging in which 62 percent of consumers choose halal logo as the main thing to read. In line with the study of Devi et. Al. (2013) who sees that halal labels is considered when making a purchase. In addition, the effect of halal labeling makes consumers feel confident and confident about the halalness of imported food products in packaging (Sari and Sudardjat 2013). Dewantara research respondents (2014) states that they rarely pay attention to the halal certification number and rarely make complaints against food products that do not have halal label. Other studies have also shown that net weight is a label attribute that is often read by consumers (Susanto 2008: Swamilaksita 2008, Maradhika 2012, Devi et al. 2013; Septian 2013; Chopera et al 2014; Dewantara 2014; Mediani 2014; Suprapto et al 2014; Toiba 2015; Puspitalena 2016).

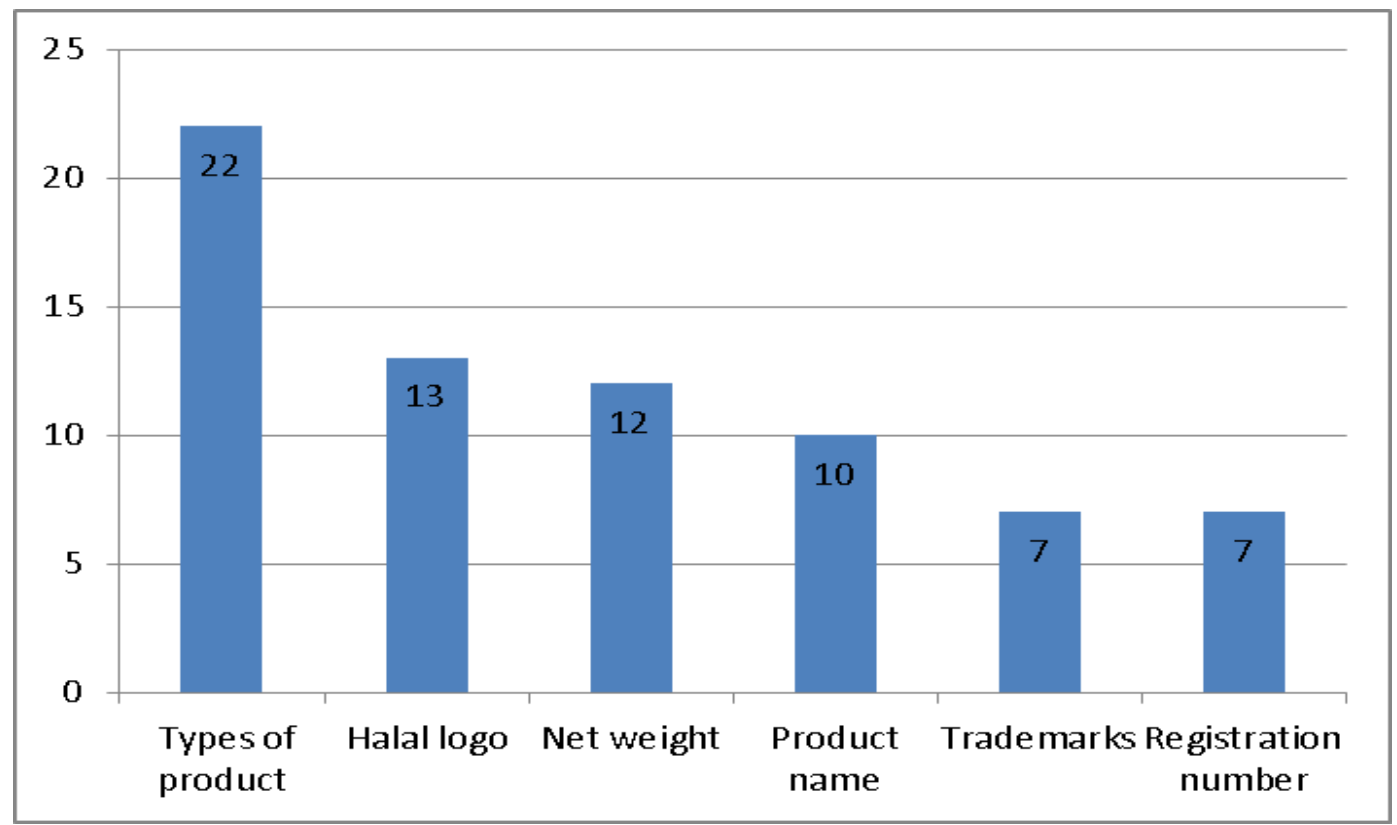

Figure 3 Label front which is often read consumer

The back part of labels that are often read by consumer (Figure 3) is the nutritional value information (Aulawi 2005; Ginting 2006; Kleef et. Al., 2007; 
Sihombing 2008; Swamilaksita 2008; Syarifah 2009; Barreiro-Hurle et. Al., 2010; Grunert et. Al. 2010; Campos et al. 2011; Hong et al. 2011; Lin et al. 2011; Da Costa Souza et al. 2011; Usfar and Fahmida 2011; Besler et al., 2012; De la CruzGongora et. al., 2012; Graham and Jeffery, 2012; Kumalasari and Sjafei 2012; Maradhika 2012; Vemula et. al.2012; Watson et. al., 2012; Devi et. al., 2013; Nurhasanah, 2013; Septian, 2013; Azman and Sahak 2014; Cannoosamy et. al. 2014; Cooke and Papadaki 2014; Dewantara 2014; Mediani 2014 Suprapto et. al., 2014; Miller and Cassady 2015; Toiba 2015; Andrew 2016; Fadlillah 2016; Huda 2016; Puspitalena 2016), composition ( Aulawi 2005; Ginting 2006; SIH 2008; Susanto, 2008; Swamilaksita 2008; Syarifah 2009; Usfar and Fahmida 2011; Maradhika 2012; Vemula et. al.2012; Devi et. al., 2013; Septian, 2013; Chopera et. al. 2014;Dewantara 2014; Mediani 2014; Suprapto et. Al. 2014; Miller and Cassady 2015; Toiba 2015; Andrias 2016; Fadlillah 2016; Puspitalena 2016), expiration (Ginting 2006; Susanto, 2008; Swamilaksita 2008; Usfar and Fahmida 2011; Herath 2012; Maradhika 2012; Vemula et. Al.2012; Devi et. Al., 2013; Septian, 2013; Chopera et. Al. 2014; Dewantara 2014, Mediani 2014, Widuri 2014, Suprapto et al 2014; Toiba 2015; Fadlillah 2016; Puspitalena 2016), product description in the form of indication (Aulawi 2005); Explanation of product storage (Chopera 2014); (Kelly 2009), 90 percent of respondents in Kelly's (2009) study felt that consistent front-of-pack on packaging made it easier for consumers to read it (90\%) (Kelly 2009), And vegetarian symbols (Vemula 2013).

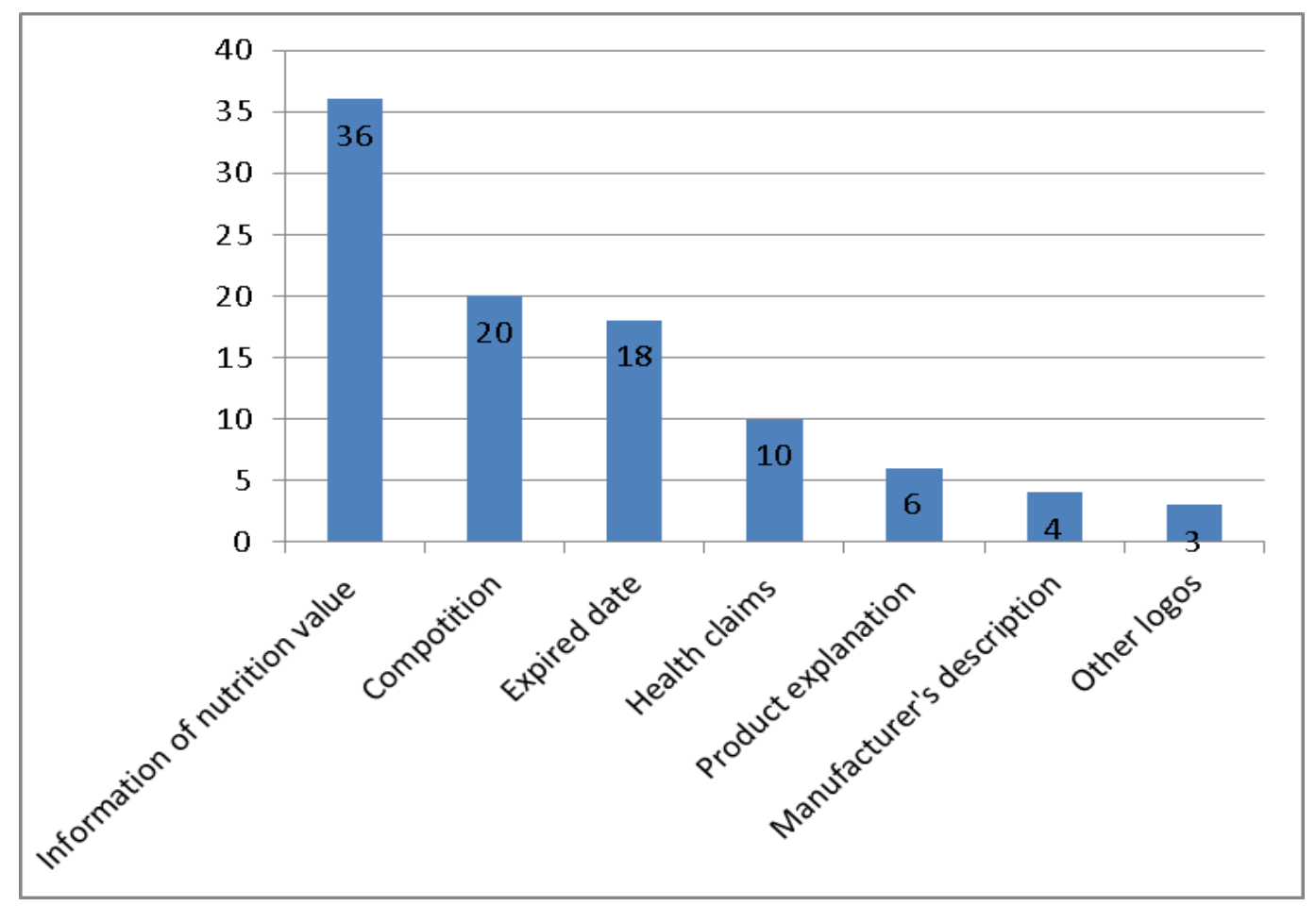

* barcode, front-of-pack, vegetarian simbol

Figure 4 Label of the back that is often read consumer 


\section{Types of Food Products Used to Read Label}

Commonly labeled food products whose labels were commonly read were Ginting food packaging 2006; Kleef et. Al. 2007; Barreiro-Hurle et. Al. 2010; Campos et. Al. 2011; Kelly et. Al. 2009; Usfar and Fahmida 2011; Isaac and Zabil 2012; Kumalasari and Sjafei 2012; Vemula et. Al.2012; Sari and Sudrardjat 2013; Septian 2013; Devi et. Al. 2013; Azman and Sahak 2014; Miller and Cassady 2015; Saunders et. Al. 2015; Toiba 2015; Andrias 2016; Huda 2016; Tonkin et. Al. 2016) and milk growth (Sihombing 2008; Ruwani et al. 2014; Suprapto et al. 2014; Puspitalena 2016). According to Suprapto (2014) women tend to consume milk growth compared to men.

In addition, consumers often read labels on food products such as frozen food packaging (Grunert et al. 2010), snacks (Ruwani et al 2014), instant noodles (Ruwani et al 2014), beverages such as soda, soda Low-calorie, tea / coffee, juice, energy drinks (Maradhika 2012; Kurnia et al. 2016), MPASI (Herlina 2008), formula milk, pregnant / breastfeeding milk (Sihombing 2008), probiotic drinks (Swamilaksita 2008; ); Cereals and cooking oil (Azman and Sahak 2014); And supplements (Aulawi 2005). Research on labels still tends to be widespread in packaged food products and only 16 out of 52 studies are examining specific food products.

\section{Perceptions and Knowledge of Packaging and Information on Labels}

\section{Food Packaging Design}

Natdjaja et. Al. (2009) says that the packaging design generally preferred by producers in Kediri Regency is packaging whose color is contrast, in which there are writing and brand, which look good and attractive, efficient, prestigious, have characteristic, environmentally friendly, sterile and hygienic. Moreover, it is easy to read and understand. Furthermore, it is also innovative so as to respond to market needs. In addition, it is found in Priatama's research (2006) where packaging is attractive, practical, and color packaging.

\section{Claim}

The claim of nutrient content is a claim that describes the content of nutrients in food as for the comparative claim of nutrients. It compares the content of nutrients and / or energy content between two or more foods (PUSPitalena 2016). Similar studies have also been found where consumers tend to notice nutritional claims in food products (Herlina 2008; Sihombing 2008; BarreiroHurle et al. 2010; Grunert et al. 2010; Hong et al. 2011; Da Costa Souza et al. 2011; Miller and Cassady 2015; Puspitalena 2016). The Puspitalena Research (2016) proves that only 12 nutritional and health claims are expressed by more than 50 percent of respondents as new information, namely: (1) Protein helps build and repair tissues; (2) Protein is an essential component in the growth and development of the child, (3) Vitamin A can help maintain the integrity of the surface layer (eyes, gastrointestinal tract, respiratory tract, and skin); (5) With iron linoleic (LA) and alpha linolenic acid (ALA) as essential fatty acids; (7) With complete and balanced nutrition / complete and balanced nutrition can help your child's growth; (8) Source / high protein; (9) Source / high vitamin; (10) Source / 
mineral height; (11) With prebiotics / Inulin / FOS / GOS; (12) As well as with Linoleic Acid / Omega 3

Health claims are any representation that states, suggests or implies that there is a relationship between a food or a substantial element of the food with health, consisting of a claim of nutrient function, other function claims, and disease risk reduction claims (CAC 2013) . Syarifah's research (2009) proves that women tend to believe in product health claims. Similar studies have found that consumers are interested in health claims (Sihombing 2008, Barreiro-Hurle et al, 2010, Azman and Sahak 2014, Miller and Cassady 2015).

This proves that the claim of nutrition and health is considered to be a means of education to know new information by consumers - 14 percent and 86 percent of the consumers is influenced by external factors, such as advertising, internet, or at school (Puspitalena 2016). This research is not in line with Susanto (2008) who found that the price became the first factor to be considered by consumers as much as 44.7 percent. Based on Ellis's quote et. Al. (2009) in Saunders et. Al. (2015) states that consumers will pay more if the product meets animal welfare standards.

According to Tricahyono et. Al. (2015), the green product label on bottled drinking water is great for its urgency. It is based on the consistency of the answers of all consumers who really hope that there is a new breakthrough in the drinking water industry to take part in saving the earth from damage caused by the amount of waste or waste caused by the industrial world. The research has found that many of the most interesting claims and claims read by consumers are health claims and nutritional claims.

\section{Food Additives}

Fadlillah Research (2016) on Food Supplementary Material (BTP) is BTP perisa, flavor enhancer, sweetener, preservative, and dye. Respondents aged 15 to 24 years are more familiar with the term BTP than respondents aged $>24$ years. The main source of BTP information for groups of 15 to 24 years can be found on the internet and school / college. While in groups $>24$ years, BTP information is mainly obtained from television. Majority of respondents thought BTP information was important and could influence purchasing decisions and showed the most attention to BTP flavorings and flavor enhancers. In addition, this study also proved that both respondents aged 15 to 24 years and $>24$ years showed the greatest attention to the BTP flavor and flavor enhancer.

Price factor is quite important for respondents in choosing food products containing food additives. Respondents have realized that BTPs added to food have certain functions (Fadlillah 2016). Overall, the term BTP is already known by most consumers spanning ages 15 to 24 .

\section{Halal Logo}

The results of Susanto's (2008) study proves that the kosher label is ranked first considered by consumers. The halal label of yoghurt products in Syarifah (2009) research is also a major consideration when buying because of the presence of gelatin content that is feared using unlawful materials. Usfar and Fahmida (2011) stated that halal label is a consideration of consumers when buying after brand and expiration. Respondents of Sari and Sudrardjat (2013) 
have knowledge of halal labeling on food products in packs with 52 respondents $(63,41 \%)$ who answered agree on the use of halal label. Dewantara's study (2014) compared sex-based knowledge, which is more than half $(56.7 \%)$ of male respondents and almost half $(44.4 \%)$ of female respondents had knowledge of halal label of food products in both categories as well as more women knowledge of food labels rather than men. Kurnia et. Al. (2016) also proves that women pay more attention to halal labels on products than men. Seven studies stated that the halal label became one of the attributes to be considered and read as well as consideration of consumers buying food products.

\section{Health messages about non-contagious diseases on packaging labels}

Respondents in the Aulawi study (2005) consumed supplemental stamina products during tired conditions $(68.7 \%)$, which were influenced by consumer confidence over product health claims. However, Swamilaksita's (2008) study only showed that 4.8 percent of respondents chose probiotic drink products because of health claims and 3.8 percent that made health claims a major concern when buying. Syarifah (2009) proves that women tend to believe in product health claims. Fadlillah's (2016) study focusing on age groups suggests that ages 15 to 24 make health claims a major concern when buying food products. Puspitalena (2016) states that 24 percent of consumer purchase decision makers is health claims.

\section{Relationship between Reading Label with Nutrition Knowledge and Influence of Label Reading Behavior with Purchasing Food Packaging}

The label reading behavior is a consumer action in reading the labels on food products (Mediani 2014) and has a relationship with the nutritional knowledge of consumers (Aulawi 2005; Ginting 2006; Herlina 2008; Sihombing 2008; Susanto 2008; Swamilaksita 2008; Syarifah 2009; Barreiro-Hurle et. Al. 2010, Grunert et al. 2010). Campos et. Al. (2011) proves that younger age and women are more knowledgeable about nutrition information labels than males (Mediani 2014). Kurnia et. Al. (2016) proves that women are more knowledgeable about high nutritional and educational knowledge related to one's nutritional knowledge. In contrast to Thistle (2014), this proves that men tend to have a higher knowledge of labels than women. Fadlillah's (2016) study looking at the demographics of consumer characteristics also proves the relationship between education and income on label reading behavior. Based on several studies above. This shows that there is a relationship between reading the label with nutritional knowledge and the influence of label reading behavior with the purchase of food packaging.

\section{Information on Labeled Considerations at the Time of Purchase}

Consumers have consideration when buying food products based on several factors, namely:

1. Trademarks, expiration, halal label (Usfar and Fahmida 2011)

2. Expiration $(75.6 \%)$, price $(53.4 \%)$, composition $(50 \%)$, manual usage (44.4\%), net weight (25.6\%) Chopera et. Al. 2014) 
3. Health claims, BTP information, net weight (age 15-24 years) registration number, producer, net weight (age $>24$ years) (Fadlillah 2016)

4. Halal label (36.5\%), expired (34.9\%), brand (20.6\%), composition (7.9\%) (Susanto 2008)

5. Price $(88 \%)$, net weight $(86 \%)$, expiry $(78 \%)$, manual use $(57 \%)$, nutrition information (56\%), composition (56\%), health and nutrition claims $(54 \%)$ PUSPitalena 2016)

6. Product name (61.2\%), product type (39.8\%), expiration (33.2\%), halal label (25.5\%), composition, usage instructions, nutrition value information, net weight, (Dewantara 2014; Mediani 2014)

7. Expired (57.1\%), information on nutritional value $(24.8 \%)$, price $(16.2 \%)$, health claims $(3.8 \%)$ (Swamilaksita 2008)

8. Halal label (95\%), nutritional value information (92.5\%), expiration (90\%), barcode $(72.5 \%)$, consumer voice $(52.5 \%)$.

9. Price $(54 \%)$, nutrition value information $(22 \%)$, trademark $(20 \%)$ (Herlina 2008)

10. Trade names (85\%), expiration (80\%), composition (20\%) (Vemula et al.2012)

\section{Conclusion}

\section{Conclusion and Suggestion}

The results showed that the frequency of reading labels on packaging products tended to be included in the category of low. Some research results showed that most consumers do not read labels due to the lack of information and the habit of buying the same product. Behavior of label reading is more often done by women than men. The most commonly read product labels on the front are the halal logo and nutritional claims for milk purchases of children aged 1-3 years. Consumers in urban areas tended to prefer to read previous labels before buying products compared to consumers in rural areas. There is a relationship between label reading habits and increasing nutritional knowledge. There is the influence of the habit of reading the label on the purchase of food packaging. The information to be considered in reading labels is brand, expiration date, and halal label.

\section{Suggestion}

Related research on label of food packaging is expected to examine the following points further:

1. Consumer with heterogeneous demography (Herawati 2012; Dewantara 2014; Mediani 2014; Ruwani et al. 2014; Thistle 2014; Miller and Cassady 2015; Toiba 2015; Fadlillah 2016);

2. Research on one type of packaged food product (Ruwani et al 2014),

3. Variables for food expenditure and calorie calculations (Toiba 2015),

4. Other packaged food products (Maradhika 2012; Puspitalena 2016),

5. Further consumer knowledge of food labeling regulations (Maradhika 2012),

6. The influence of product labels on consumer perceptions (Septian 2013),

7. Which parts of the label are the main factors of consumer purchase decision (Susanto 2008; Dewantara 2014), 
8. Other factors that influence label reading behavior on consumers (Mediani 2014),

9. Variables such as lifestyle, motivation, attitude, personality, self concept (Widuri 2014)

10. To examine further on consumer types and values (Ruwani et al 2014),

11. Researching further about the intention of repurchasing products (Herawati 2012),

12. Criteria of consumer confidence in health claims (Syarifah 2009),

13. To examine more deeply about consumer purchasing decisions due to the knowledge of labels (Da Costa Souzaet, Al. 2011, Watson et al., 2012)

14. Consumer purchase decision due to nutritional information information information (Kleef et al 2007, Azman and Sahak 2014),

15. Researching in areas not expected to know about nutritional value information label (Azman and Sahak 2014),

16. Need cross-tabulation analysis of the variables studied especially related to consumer characteristics with label reading behavior. The goal is to do the right education on a particular segmentas,

17. Until now a lot of researched is a halal logo, while many other logos can still be explored, such as go green logo,

18. The portion of the label that consumers are concerned with whether the front or back needs to be studied further,

19. There is still little study of reading health messages on labels,

20. Only a few distinguish label reading behavior by region (eg village-town),

21. There is still little study of consumer impressions of the size and type of writing on the label,

22. Need more specific analysis of products containing food additives

\section{Acknowledgement}

This research was supported by PT. Unilever lndonesia Tbk. We are also immensely grateful to all participants in dissemination session for their comments on an earlier version of the manuscript.

\section{References}

Andrias, D.R. (2016). Nutrition label use of pre-packaged food among university students in Surabaya, Indonesia.4th Asian Academic Society International Conference (AASIC) 2016 Globalizing Asia: Integrating Science, Technology and Humanities for Future Growth and Development.

Aulawi, T., (2005). Preferensi Konsumsi Beberapa Produk Suplemen Penstimulasi Stamina.[Tesis]. Bogor: Institut Pertanian Bogor.

Azman, N., Sahak S.Z. (2014). Nutritional label and consumer buying decision: a preliminary review. Procedia-Social and Behavioral Sciences 130.490498.

Barreiro-Hurle J, Gracia A, de-Magistris T. (2010). Does nutrition information on food products lead to healthier food choices?.Food Policy.221-229. 
Besler, H.T., Buyuktuncer Z, Uyar MF. (2012). Consumer understanding and use of food and nutrition labeling in Turkey. Journal of Nutrition Education and Behavior. 44(6): 584-591.

Campos, S., Doxey, J., Hammond, D. (2011). Nutrition labels on pre-packaged foods: a systematic review. Public Health Nutrition. 14(8): 1496-1506.

Cannoosamy, K., Pugo-Gunsam P., Jeewon R. (2014). Consumer knowledge and attitudes toward nutritional labels.Journal of Nutrition Education and Behavior. 46(5): 334-340.

Cooke, R., Papadaki, A. (2014). Nutrition label use mediates the positive relationship between nutrition knowledge and attitudes towards healthy eating with dietary quality among university students in the UK. Appetite 83.297-303.

Chopera, P., Chagwena, D.T., Mushonga, N.G.T. (2014). Food label reading and understanding in parts of rural and urban Zimbabwe. African Health Sciences. 4(3): 576-584.

Da Costa Souza SMF, Lima K.C, Miranda HFd, Cavalcanti eFID. (2011). Utilização da informação nutricional de rótulos por consumidores de Natal, Brasil.Rev Panam Salud Publica. 29(5): 337-343.

De la Cruz-Gongora V, Villalpando S, Rodriguez-Oliveros G, Castillo-Garcia M, Mundo-Rosas V, Meneses-Navarro S. 2012. Use and understanding of the nutrition information panel of pre-packaged foods in a sample of Mexican consumers.Salud pública de méxico. 54(2): 158-166.

Devi VC, Sartono A, Isworo JT. 2013. Praktek pemilihan makanan kemasan berdasarkan tingkat pengetahuan tentang label produk makanan kemasan, jenis kelamin, dan usia konsumen di pasar swalayan Ada Setiabudi Semarang. Jurnal Gizi Universitas Muhammadiyah Semarang.2(2): 1-12.

Dewantara, M.M. (2014).Pengetahuan, Nilai Religiusitas, Sikap, dan Perilaku Membaca Label Halal pada Mahasiswa. [Skripsi]. Bogor: Institut Pertanian Bogor.

Fadlillah, H.N. (2016). Kepedulian Konsumen Terhadap Label dan Informasi Bahan Tambahan Pangan (BTP) pada Label Kemasan Pangan di Kota Bogor. [Tesis].Bogor: Institut Pertanian Bogor.

Ginting, A.,A.,F.,B. (2016). Faktor-Faktor yang Berhubungan dengan Kebiasaan Membaca Label Kemasan Pangan pada Mahasiswa FKM USU Medan 2015. [Skripsi]. Medan: Universitas Sumatera Utara.

Ginting, E. (2006). Persepsi Ibu tentang Label Makanan Kemasan Anak Sekolah Dasar.[Skripsi]. Bogor: Institut Pertanian Bogor.

Graham, D.J ., Jeffery, R.W. (2012). Predictors of nutrition label viewing during food purchase decision making: an eye tracking investigation. Public Health Nutr.15(2): 189-197.

Grunert, K.G., Wills, J.M., Fernandez-Celemin, L., Bonsmann, S.S.G., Nureeva L. (2010). Use and understanding of nutrition information on food labels in six European countries.J Public Health. 18:261-277.

Grunert KG, Wills JM, Fernandez-Celemin L. 2010. Nutrition knowledge, and use and understanding of nutrition information on food labels among consumers in the UK.Appetite.177-189. 
Herawati, V. (2012).Pengaruh persepsi kualitas produk terhadap niat pembelian ulang pada private label "Carrefour" di Carrefour melalui kepuasan konsumen sebagai variabel mediasi.JUMMA.1(3).

Herlina, E. (2008). Kajian Kesesuaian Produk Makanan Pendamping Air Susu Ibu (MP-ASI) dengan Standar Nasional Indonesia dan Kontribusi terhadap Kecukupan Gizi Bayi/Anak.[Tesis]. Bogor: Institut Pertanian Bogor.

Hong, Z.H,, Wang, S.F., Liu, M., Yang, Y.P., Chen, Y., Liu, Q.M. (2011). Study on knowledge, attitudes and use of the pre-packaged food nutrition labeling in Hangzhou supermarket consumers in 2010. Chinese Journal of Epidemiology.32(7): 657-660.

Huda, Q.A. (2016). Hubungan Pengetahuan dan Sikap dengan Perilaku Membaca Informasi Nilai Gizi dan Pemilihan Pangan Kemasan. [skripsi]. Surabaya: Universitas Airlangga.

Ishak, S., Zabil, N.F.M,. (2012). Impact of consumer awareness and knowledge to consumer effective behavior. Asian Social Science.8(13): 108-114.

Kelly, B., Hughes, C., Chapman, K., Louie, JC, Dixon H, Crawford J, King L, Daube M, Slevin T. (2009). Consumer testing of the acceptability and effectiveness of front-of-pack food labeling systems for the Australian grocery market.Health Promotion International. 24(2): 120-129.

Kleef, E.V., Trijp, H.V., Paeps. F., Fernandez-Celemin, L. (2007). Consumer preferences for front-of-pack calories labeling.Public Health Nutrition. 11(2): 203-213.

Kumalasari H, Sjafei NJ. (2012). Analyzing the effect of health and appearance consciousness on intention to calculate calorie information if displayed at fast food restaurant menu. Journal of Business Strategy and Execution. 4(2): 115-142.

Kurnia, P., Wardhani DTK, Hariyani R. (2016). Consumer attitudes, nutrition knowledge, and use of nutrition information on the labels of packaged drinks among adolescents in Surakarta, Indonesia.International Conference on Health and Well-Being.253-264.

Lin, W., Hang C, Yang H, Hung M. 2005-2008 Nutrition and health survey in Taiwan: the nutrition knowledge, attitude and behavior of 19-64 years old adults. 2011. Asia Pac J Clin Nutr. 20(2): 309-318

Maradhika, V. (2012). Kajian Pemenuhan Syarat Label Minuman Sari Buah (Kemasan Siap Minum) di

Beberapa Pasar Swalayan Kota Bogor.[Skripsi]. Bogor: Institut Pertanian Bogor.

Mediani, N.V. (2014). Pengetahuan, Persepsi, Sikap, dan Perilaku Membaca Label Informasi Gizi pada Mahasiswa. [Skripsi]. Bogor: Institut Pertanian Bogor.

Miller, L.M.S., Cassady, D.L. (2015). The effects of nutrition knowledge on food label use. A review of the literature.Appetite 92.207-216.

Natadjaja, L., Cahyono, Y.B., Yuwono, EC. (2009). Kondisi desain kemasan produk makanan ringan dan minuman insta.nt pada industri kecil skala rumah tangga (micro industry) di Kabupaten Kediri. Jurnal desain komunikasi visual nirmana. 11(2). 
Nurhasanah, A.R. (2013). Hubungan Persepsi dan Perilaku Konsumen di DKI Jakarta terhadap Label Gizi Pangan dengan Status Gizi dan Kesehatan. [Skripsi]. Bogor: Institut Pertanian Bogor.

Pratama, F. (2006). Analisis Brand Equity Pocari Sweat dalam Persaingan Industri Minuman. [Skripsi]. Bogor: Institut Pertanian Bogor.

Puspitalena, A. (2016). Klaim Gizi dan Kesehatan pada Label Produk Susu Pertumbuhan dan Peranannya sebagai Sarana Edukasi dan Penentu Keputusan Pembelian.[Tesis]. Bogor: Institut Pertanian Bogor.

Ruwani, A., Retnaningsih., Simanjuntak, M. (2014). Nilai dan tipe konsumen rumah tangga dan kaitannya dengan perilaku pembelian produk makanan kemasan.Jur. Ilm. Kel. \& Kons. 7(1): 48-57.

Sari, D.K., Sudardjat, I. (2013). Analisis pengaruh labelisasi halal terhadap keputusan pembelian produk makanan impor dalam kemasan pada mahasiswa kedokteran Universitas Sumatera Utara.Jurnal Ekonomi dan Keuangan.1(4): 49-56.

Saunders, C.M., Guenther, M., Tait, P.R., Dalziel, P.C. (2015). Consumer attitudes towards attributes of food and the use of digital media and smart technologies to inform and purchase food. Contributed Paper prepared for presentation at the 89th Annual Conference of the Agricultural Economics Society, University of Warwick, England.

Septian, J. (2013). Kondisi dan Persepsi Industri Rumah Tangga Pangan (IRTP) tentang Label Kemasan Pangan (Studi Kasus di Kota Bogor). [Skripsi]. Bogor: Institut Pertanian Bogor.

Sihombing, T.H. (2008). Kajian Klaim Gizi dan Kesehatan pada Produk Pangan untuk Bayi dan Anak Balita serta Ibu Hamil dan Menyusui. [Tesis]. Bogor: Institut Pertanian Bogor.

Sumarwan U. (2011). Perilaku Konsumen. Bogor: Ghalia Indonesia.

Suprapto, D.A., Nurmalina, R., Fahmi, I. (2014). Faktor-faktor yang memengaruhi keputusan konsumen dalam pembelian produk susu bubuk pertumbuhan. Jur. Ilm. Kel. \& Kons. 7(2): 113-122.

Susanto. (2008). Pengaruh Label Kemasan Pangan terhadap Keputusan Siswa Sekolah Menengah Atas dalam Membeli Makanan Ringan di Kota Bogor. [Skripsi]. Bogor: Institut Pertanian Bogor.

Swamilaksita, P.D. (2008). Konsumsi dan Persepsi Manfaat Minuman Probiotik pada Lansia di Kota Bogor. [Skripsi]. Bogor: Institut Pertanian Bogor.

Syarifah, S.S. (2009). Kepercayaan terhadap Klaim Kesehatan Pencernaan dan Kepuasan Konsumen Yoghurt Activia di Kota Bogor. [Skripsi]. Bogor: Institut Pertanian Bogor.

Toiba, H. (2015). A Study of the Relationship between Modern Food Retail Penetration and Urban Indonesian Consumers' Food Shopping Behaviour, Consumption and Dietary Patterns. [Tesis]. Australia: The University of Adelaide.

Tonkin, E., Meyer, S.B., Coveney, J., Webb, T., Wilson, A.M. (2016). The process of making trust related judgements through interaction with food labeling. Food policy 63.1-11.

Tricahyono, H.A., Yulisetiarini, D., Irawan, B. (2015). Urgensi label green product pada air minum dalam kemasan di Kota Jember. Artikel ilmiah mahasiswa. 
Usfar, A.A, Fahmida, U. (2011). Do Indonesians follow its Dietary Guidelines? evidence related to food consumption, healthy lifestyle, and nutritional status within the period 2000-2010. Asia Pac J Clin Nutr.20(3): 484-494.

Vemula, S.R., Gavaravarapu, S.M., Mendu, V.V.R., Mathur, P., Avula, L. (2012). Use of food label information by urban consumers in India - a study among supermarket shoppers.Public Health Nutrition. 17(9): 2104-2114.

Watson, W.L., Chapman, K., King, L., Kelly, B., Hughes, C., Louie, J.C.Y., Crawford J, Gill TP. (2012). How well do Australian shoppers understand energy terms on food labels?.Public Health Nutrition. 16(3): 409-417.

Widuri, R.N. (2014). Pengetahuan, Persepsi Risiko, dan Perilaku Membaca Label Kadaluarsa Produk Pangan. [Skripsi]. Bogor: Institut Pertanian Bogor. 